\title{
Upheavals of Emotions, Madness of Form: Mary M. Talbot's and Bryan Talbot's Dotter of Her Father's Eyes and a Transdiegetised (Auto)Biographical Commix
}

\section{Robert Kusek}

In 2012, Mary M. Talbot and Bryan Talbot joined the likes of Richard Ellmann, Gordon Bowker and Michael Hastings and in their graphic memoir Dotter of Her Father's Eyes (2012) offered a new re-telling of James foyce's life, focusing, in particular, on the difficult relationship between the great Irish writer, and his daughter Lucia. However, the story of a complicated emotional bond between Foyce and Lucia was only a framework for an autobiographical coming-of age narrative about Mary $M$. Talbot herself and her violent relationship with fames $S$. Atherton, a celebrated foycean scholar and her very own "cold mad feary father". Following Martha C. Nussbaum's conception about cognitive and narrative structure of emotions postulated in Love's Knowledge (1990) and Upheavals of Thoughts (2001), this article wishes to argue in favour of an organic connection between the volume's thematic concerns and its generic affiliation. In other words, it discusses how a specific class of emotions pertaining to Lucia's gradual mental disintegration can be adequately told only in a specific literary form, i.e. in a transdiegetised "commix", an (auto)biographical account which occupies a threshold space between a comic and a novel, fiction and non-fiction, biography and autobiography, words and pictures.

Keywords

Life writing; commix; Lucia Joyce; Mary M. Talbot

The more I said I had a physical illness, the more they said I had a mental illness. The more I questioned the nature, the reality of the mental illness, the more I was found to be in denial, deluded. [...] Every time I spoke I dug myself into a deeper hole (Mantel 177, 181). 
We learn our emotional repertory, in part at least, from the stories we hear (Nussbaum 1992, 312).

She was like the high, perishable, wishful tendril of a vine moving blindly up the wall (A friend of Lucia Joyce quoted in Saunders 84).

\section{Lucia Joyce's Bioi}

In this, our very own age of biography ${ }^{1}$, neither James Joyce nor members of his family have been spared some considerable investigation of their bios (or, to be more accurate, $\left.b i o i^{2}\right)$ by various practitioners of life narratives. Over the last three decades, disciples (and, inevitably, rivals) of Richard Ellmann 3 have, many a time, re-told the lives of the Joyces: the Modernist literary artist himself ${ }^{4}$, his wife ${ }^{5}$ and father ${ }^{6}$, among others. However, the figure that seems to have recently attracted the greatest attention of critics and readers alike is Lucia Joyce, James Joyce's beloved "blueveined child"7. Occupying a marginal position in her father's canonical biography ${ }^{8}$, Lucia's ${ }^{9}$ untold story first came to prominence when in 1988, Stephen J. Joyce, the son of Giorgio and grandson of James, forced Brenda Maddox to remove an epilogue pertaining to Lucia and entitled "Her Mother's Daughter" from Maddox's biography of Nora Barnacle - a controversial demand which received wide coverage in the media $^{10}$. The scandal most certainly precipitated interest in Lucia Joyce's story as in 1992 a biographical novel about Lucia was published. Written by Alison Leslie Gold and entitled Clairvoyant: the Imagined Life of Lucia Foyce (1992), this specimen of biofiction $^{11}$ focused in particular on Lucia Joyce's struggle with mental illness (which Gold imagined, alongside others, to be schizophrenia ${ }^{12}$ ) and on her final years spent in isolation. In 2003, exactly fifteen years after the release of her mother's abridged biography, Lucia Joyce's life story was narrated by the literary scholar Carol Loeb Shloss - though this time acts of censorship and threats of lawsuits formulated by Stephen J. Joyce were also not avoided (Smith). Not only is Lucia foyce: To Dance in the Wake (2003) an act of "seeing [Lucia's story] with fresh eyes [...], an act of survival" (Rich 35), but also an attempt to "valoriser" (i.e., re-valuate [Genette 483]) the character of Joyce's mad daughter. Shloss, indeed, invests Lucia with a more significant or "attractive" role, and her transformation is both psychological and pragmatic ${ }^{13}$. The writer's daughter is sexually uninhibited (enjoying both heterosexual and homosexual relations), a beautiful and highly talented 
dancer adored by the Parisian artistic milieu, a writer in her own right (whose novel has been irretrievably lost) and - most importantly - a "silent partner" (Shloss 10) and major source of inspiration for her father's work, including Finnegans Wake 14 (1939).

Carol Loeb Shloss's groundbreaking biographical study certainly paved the way for further explorations of Lucia Joyce's life. In March 2004, in London's West End, a new play by Michael Hastings opened. Set in Paris in 1928, Calico (2004) narrates Lucia's infatuation with Samuel Beckett whose rejection leads to Lucia's mental instability and subsequent institutionalisation. The playwright's motivation was quite similar to that of Lucia's biographer, namely to rescue a marginalised figure who - in a dramatised version of her life - suffered primarily from the burdensome proximity and imperviousness of Modernist icons ${ }^{15}$. Lucia Joyce also featured prominently (and quite unexpectedly) in Frances Stonor Saunders's 2010 biography of Violet Gibson entitled The Woman Who Shot Mussolini (2010). Like Lucia Joyce, Gibson was incarcerated in St. Andrew's Hospital in Northampton and the two women remained in the adjoining rooms for half a decade ${ }^{16}$. Saunders's biographical study finally provided scholars with some valuable information (including a previously unpublished photograph of Lucia taken five years before her death) on Lucia's (largely) unrecorded period of life: a period marked by considerable loneliness and misery ${ }^{17}$.

In 2012, a corpus of biographical pieces dedicated to Lucia Joyce was enlarged by publication of a graphic biography of Lucia jointly conceived and produced by Mary M. Talbot (a writer) and her husband Bryan Talbot (a draughtsman). However, it turned out that the aim of this artistic collaboration was not simply to narrate the life of Lucia in a new, previously untried medium (i.e., comics). On the contrary, the story of the complicated emotional bond between Joyce and Lucia was primarily a framework for an autobiographical coming-of age narrative about Mary $\mathrm{M}$. Talbot herself and her violent relationship with James S. Atherton, a celebrated Joycean scholar and her very own "cold mad feary father" (Joyce 628). Consequently, the present article wishes to provide a comparative reading of the biographical and autobiographical sections of the volume. What is more, following Martha C. Nussbaum's conception about cognitive and narrative structure of emotions postulated in Love's Knowledge and Upheavals of Thoughts, it hopes to argue in favour of an organic connection between the book's thematic concerns and its complicated generic affiliation. In other words, the article discusses how a specific class of emotions pertaining to Lucia's (and, partly, Mary's) gradual 
mental disintegration can be adequately told only in a specific literary form, i.e., in a transdiegetised "commix", an (auto)biographical account which occupies a threshold space between a comic and a novel, fiction and nonfiction, biography and autobiography, words and pictures.

\section{Madness of Form}

One of the most conspicuous manifestations of the borderline nature of the Talbots' book is its deliberate resistance to separate the life stories of Lucia and Mary; hence, individual panels of images are not grouped in distinctive structural units (e.g., sections or chapters ${ }^{18}$ ) but organised as a single narrative in which the episodes concerning Joyce's daughter are constantly interwoven with those about the female offspring of his foremost scholar.

Dotter of Her Father's Eyes is by no means an unorthodox or revisionist biography of Lucia Joyce. The "responsibility to likeness and the need for accuracy" (Lee 28) that seems to govern most biographies is visible in the Talbots' decision to adhere to the findings and interpretations of Lucia's life that have been offered by Carol Loeb Shloss ${ }^{19}$. Mary M. Talbot refuses to concoct or invent stories about Lucia; instead, her following of the story narrated in Lucia foyce: To Dance in the Wake is so religious that she begins her narrative about Joyce's daughter with the very same episode that opens the first chapter ("The Curtain Opens. Trieste 1907-15") of Shloss's book, namely with Joyce reading to Lucia and making up songs in Italian: "C'era una volta, una bella bambina/Che si chiamava Lucia" (Shloss 37 and Talbot 26).

To say that Dotter of Her Father's Eyes is - diegetically - "imprisoned" by the master narrative of Shloss is nothing short of exaggeration. After Shloss (and, more famously, Carl Gustav Jung), Talbot sees her protagonist as Joyce's femme inspiratrice $e^{20}$ - not only a companion of Joyce's explorations of the world of the avant-garde cinema, theatre and ballet, but his major source of inspiration: "She watched him create", while "he watched her dance" (Talbot 27). Throughout the narrative, Lucia is presented as a woman who far exceeds her peers and whose genius is largely ignored by her family. She alone embraces "an education in eccentricity" (i.e. she studies modern dance [Talbot 45]) and remains tuned to the latest achievement of modern art. The images drawn by Bryan Talbot show Lucia in the company of such Modernist artists as George Antheil, Pablo Picasso, Marcel Duchamp, Man Ray and Erik Satie. In fact, Talbot shows Lucia as far more unconventional and avant-garde (in 
other words, more modern[ist $]^{21}$ ) than her father. When they meet Margaret Morris, Joyce recognises her only as a granddaughter of William Morris, a major contributor to the Arts and Crafts Movement, while Lucia knows her as an experimental dancer ${ }^{22}(45)$. The Talbots' graphic narrative also juxtaposes Lucia's desires to be la femme moderne with the reactionary, bourgeois and, essentially, misogynist views expressed by Joyce ${ }^{23}$. "It isn't seemly for women to go on stage and wave their arms and legs about", the father declares (58, emphasis in original). Elsewhere, he says: "Lucia, Lucia. Be content. It's enough if a woman can write a letter and carry an umbrella gracefully" (67, emphasis in original); and adds: "As long as you know how to walk into a room properly that is all that matters" (79, emphasis in original). The attitude of the narrative to its protagonist (and its belief in her extraordinary creative potential) seems to be best summed up by a phrase from the Paris Times interview with Lucia Joyce published in 1928 which was unearthed by Carol Loeb Shloss and diligently re-quoted by Mary M. Talbot: "When she reaches her full capacity for rhythmic dancing, James Joyce may yet to be known as his daughter's father" (55).

However, Lucia Joyce failed to "reach her full capacity" and the final panels of images show her gradual physical and mental collapse. Again, in line with Shloss's version of Lucia's story, Mary M. Talbot sees her heroine as a victim that was forced to sacrifice her life (both professional and personal) for her father's art, as "a sacrifice made to male egocentrism" (Shloss 8). Joyce's egotism is, perhaps, best manifested in a series of images showing an encounter with Madame Morris; whenever he is not in the centre of everyone's attention, he becomes irritable, bored and rude (looking at his watch, turning his back upon his interlocutors [48]). It is upon her father's advice that Lucia gives up on dancing and teaching and becomes his full-time attendant and scribe. "But - are you sure he's the best person to advise you? Can you rely on his judgement?", Stella Steyn asks her friend. "Oh, he knows everything", Lucia responds (77, emphasis in original). Lucia Joyce is thus presented as someone who internalised a belief that her father "was the sole genius in their midst whose talent had at all times to be protected and nourished" (Shloss 7).

Finally, the last act of the Talbots' complicity with Shloss can be identified in the story's ostensible "bias towards madness" (Shloss 26). Lucia is never presented as a psychotic lunatic but a person deeply victimised by her own family. With her career and health in ruins, a relationship to Samuel Beckett broken, her parents forcing her to leave Paris and announcing their own (late) marriage, Lucia (called by Nora a "bastard", "selfish cow" and "trollop" [81, 
82]) becomes prone to bouts of depression and violence. Having assaulted her mother (she throws a chair at her), she is committed by her brother Giorgio. The subsequent fifty years of Lucia's life (from 1932 to 1982) will be limited to only two pages and two images which inform the readers of Dotter of Her Father's Eyes that Lucia - declared dangerous and mad, suicidal and addicted to drugs - lived out the rest of her life under house arrest and in various institutions ${ }^{24}$.

James Olney once stated that "the finest biographies as the very condition of their being the finest biographies - always and invariably reveal clear and compelling traces (and often much more than mere traces) of autobiography" (429). This is, indeed, the case of Dotter of Her Father's Eyes which, as it has already been signalled, is vitally and ostensibly interested in narrating not only the life of Lucia Joyce, but also the one of its co-author, Mary M. Talbot. What immediately strikes the readers of the story's autobiographical sections is its uncanny similarity to Lucia's biographical narrative ${ }^{25}$. The names of Mary's parents are James and Nora (Atherton) and their background is Catholic. Like Lucia, Mary wants to become a dancer and is forced to give up on ballet classes upon her parents' demand. She also has an ear for languages and often mixes up words and phrases (e.g. "J'ai peur de devenir insane" [56]) - a characteristic feature of Lucia's own idiolect heavily influenced by her living among people speaking Italian, French and English. Finally, similarly to Joyce's daughter, Mary is a "strange" child who is considered a nuisance due to uncommon behaviour (e.g., sleepwalking) and outbursts of anger. She is also a victim of gender stereotyping as well as of physical and mental abuse frequently exercised by her "cold mad feary father" (3). James S. Atherton, the author of the seminal The Books at the Wake (1960) - a piece of criticism that is concerned with Joyce's major sources and influences - also suffers from a specific form of the "anxiety of influence". He is highly egotistical and obsessed with his own reading and writing. Known for constantly "muttering Joycean phrases" and even for looking like Joyce (20), he is the prime source of Mary's oppression ${ }^{26}$. "How sharper than a serpent's tooth it is to have a thankless child", he says at some point quoting a famous phrase from King Lear ${ }^{27}$. Though he is capable of calling Mary his "baby tuckoo"28 or "frail blueveined child" ${ }^{29}$, Atherton's most frequently used phrases addressing his daughter are: "That's enough", "Go to your room", "Get out", "Stay out", "Go away" and "I'm ashamed of you" $(23,24,29,35)$. Finally, just like Joyce, Atherton is a male chauvinist who is capable of reciting the following phrase in front of his wife and daughter: "Of all creatures women be best: Cuius contrarium verum est. And grete joy among 
them ys for it to be. Cuius contrarium verum est" (32). Though born 47 years after Lucia, Mary becomes subjected to the same set of oppressions: paternal egocentrism, gender stereotyping, negative social and family pressure, mental and physical abuse.

Consequently, in light of the above-made observations, I am tempted to see Dotter of Her Father's Eyes as a narrative governed by the principle of "transdiegetisation" (Genette 1982: 418-419) - a term I have borrowed from the transtextual lexicon of Gérard Genette ${ }^{30}$. When talking about a derivational relationship between a given text $\mathrm{B}$ and a pre-existent text $\mathrm{A}$ from which the former has been derived (13), Genette identifies a number of formal operations (called transformations or transpositions), including diegetic transformations, i.e., changes in the diegesis ("I'univers où advient cette histoire" [419]) of a given hypotext and hypertext. In other words, transdiegetisation is a procedure which allows for the transfer of an action or character from one period to another or from one location to another. In the process, historical and geographical settings are (obviously) altered as are "les événements et les conduites constitutives de l'action" since "on ne peut guère transférer une action antique à l'époque moderne sans modifier quelques actions" (442). Nevertheless, what lies at the very heart of this operation is an understanding that a hypertext narrates a story that is essentially (i.e., pragmatically but also, one could further claim, epistemologically) the same as the one told by a hypotext, while readers can recognise the very fact by means of identifying various (textual) inscriptions preserved by this new diegetic world. Dotter of Her Father's Eyes does, indeed, narrate two distinctive stories of Lucia and Mary and there is no doubt that their "vital statistics" or individual parameters differ. However, by selecting and emphasising facts (e.g., parents' names) and episodes (e.g., dance classes) that the two women share, Mary M. Talbot transdiegetises the life of Lucia and, consequently, makes an indirect claim about her own bios - namely that her life offers a reenactment of Lucia's story, that Mary is another Lucia ${ }^{31}$. Or, in fact, was, since, unlike Lucia, Mary did not end up incarcerated in an institution. Her creative potential was not smothered, but unleashed. Her very own Samuel Beckett, i.e., Bryan Talbot, did not abandon her but, instead, married her and took her away from her oppressive family. In short, he saved her from being the "dotter of her father's eyes". Nevertheless, the motto to the Talbots' graphic memoir appears to suggest that Mary does not necessarily privilege her own story only or acknowledge herself as "the other Lucia": "Once upon a time and long ago a king and a queen had a daughter. Her name was Marushka 
or Lucia or Lucy Maria or Mary" (1). By placing Lucia's and her own name in the company of other "Cinderellas" of the world, she has made a claim about the universal character of their stories (though not necessarily of their endings). The guises might be different but their stories - the stories of female subjugation and difficult, often unsuccessful resistance - are suggested to be quite the same ${ }^{32}$, regardless of differences in times and customs.

Dotter of Her Father's Eyes inevitably invites its readers to pose a number of questions concerning the narrative's generic affiliation. The story's deliberate inconsistency in terms of its subject matter (self vs. other), its complex (i.e. double) authorship ${ }^{33}$, and, consequently, impossibility to classify it as exclusively belonging to only one, clearly defined genre (autobiography vs. biography) encourage one to describe it as a memoir ${ }^{34}$, the most "threshold" literary category (Couser 12). However, since Dotter of Her Father's Eyes also offers an amalgam of words and pictures, one could further turn to a term famously proposed by Art Spiegelman, namely "commix". When talking about the unsuitableness 35 of the term "comics" when applied to his Holocaust narrative Maus (1980), Spiegelman opens his essay in the following way: "I prefer the word commix, to mix together, because to talk about comics is to talk about mixing together words and pictures to tell a story. [...] The drawings without their text would only have a vague meaning; the text without the drawings would have no meaning at all. The combination makes up a kind of novel - all the more unique in that it is no more like a novel than it is like anything else" (Spiegelman 61). Just like Maus, Dotter of Her Father's Eyes offers a number of "commix-ture(s)" (Young 2000, 18): graphic, textual, generic, and, strictly speaking, formal (fiction vs. non-fiction). Also, both narratives are equally interested in narrating the life of the other (Lucia Joyce, Vladek Spiegelman ${ }^{36}$ ) and self (Mary M. Talbot, Art Spiegelman). Finally, in both cases the emphasis is put not on an exhaustive historical reconstruction of the past lives, but on the way they have become meaningful and constitutional for understanding of autobiographical selves ${ }^{37}$.

Such a pronouncement on the piece's "genre" inescapably invites one to further dwell on the reasons for the Talbots' privileging this particular comixed form. Why writing and drawing a profoundly hybrid form, a mélange instead of two separate narratives: a graphic biography $3^{8}$ and autobiography 39 in which the field of comics clearly abounds. In order to answer this question, I should like to turn to Martha C. Nussbaum's discussion of emotions and narratives. 


\section{Upheavals of Emotions}

Since 1990, i.e., the publication of Love's Knowledge, the American philosopher Martha C. Nussbaum has been vitally interested in the relationship between emotions $^{4^{0}}$ and cognition ${ }^{41}$ as well as emotions and narrative structures ${ }^{42}$. Two claims appear to remain central to Nussbaum's thinking. First, she believes that "there is, with respect to any text carefully written and fully imagined, an organic connection between its form and its content" (Nussbaum 1992, 4). Second, certain truths about human life can be competently and accurately stated only in the language and forms characteristic of the art of literature (5). Why? Because she believes that literary works (unlike other forms of writing) are not neutral instruments for the investigation of all possible conceptions; on the contrary, they are powerfully charged with meaning. Nussbaum consequently proclaims that one should discover forms and terms that fittingly express as well as adequately state the given truths. In other words, a certain truth needs to be stated in a specific language, a specific genre and style which guarantee that a particular statement on life is, in fact, made. The truths Nussbaum writes about also include emotions, which she calls, after Proust, "geological upheavals of thoughts" (Nussbaum 2008, 1) and considers them "intelligent responses to the perception of value" (ibid.).

If a story can have a structure of feeling, as the philosopher claims (Nussbaum 1992, 299), then what kind of emotion is reflected by the form of the Talbots' commix - one may be more than tempted to ask in light of the above-made remarks. As discussed in some detail, Lucia's story as narrated by Mary M. Talbot is one involving not madness but "fear, and hope, and grief, and anger, and love" - the five basic emotions identified by Nussbaum in Upheavals of Thoughts (19). In this sense, Dotter of Her Father's Eyes - just like Molloy which Nussbaum privileges in her reading of emotions and narrative structures - has "a complex emotional structure in which guilt, fear, disgust, hope, and love do not pop up in isolation from one another, identifiable separately and singly defined. Instead, they emerge as interwoven aspects of a single narrative" (Nussbaum 1992, 297, emphasis added). Analogously, Lucia's life resembles Molloy's in being "the long confused emotion" (Beckett 25) (3. $^{4}$

Thus, if I were to answer the question concerning the relationship between the form (transdiegetised (auto)biographical commix) and content (the tumultuous emotional lives of Lucia Joyce and Mary M. Talbot) of Dotter of Her Father's Eyes, I would surmise, together with Martha C. Nussbaum, 
that the complex "geography" of the Talbots' story is governed by the narrative's desire to "inform us about the structure of emotions" inside the characters (Nussbaum 1992, 297). And since the structure of emotions is that of disintegration, concoction and confusion, the narrative - organically connected with the subject matter - may do it best by offering its readers a series of formal and narratological "commix-tures".

Leigh Gilmore once wrote that "the task of autobiography" is "how selves and milieus ought to be understood in relation to each other" (12, emphasis in original). By co-mixing Lucia's life story with that of Mary M. Talbot and, as a result, by revealing the repetitive paradigm scenarios that have been governing the lives of women, Dotter of Her Father's Eyes - this, in my belief, profoundly relational narrative - undoubtedly fulfils the function assigned to autobiography 44 by Gilmore and, consequently, makes the Talbots's graphic memoir an extraordinary example of s'y lire.

\section{Notes}

1. In her essay for the London Review of Books, Barbara Everett recapitulated on the increasing interest in what can be called the "daily existence" of writers and famously concluded: "This is an age of biography, not of poetry" (Everett 6-10). Elsewhere, Doris Lessing declared about our times: "We are enjoying a golden age of biography" (Lessing 14).

2. I am referring here to the Greek term Bio meaning "life" and, consequently, a root word for such words as biography and biofiction.

3. The author of Joyce's "definitive" biography, i.e., Fames Foyce of 1952, famously labelled by Anthony Burgess as "the greatest literary biography of the century" (Burgess qtd in Janen Kooistra 31).

4. E.g., Fames Foyce: A Life by Edna O'Brien (2000), The Years of Bloom. Fames Foyce in Trieste, 1904-1920 by John McCourt (2000), Fames foyce by Andrew Gibson (2006), Fames Foyce by Bruce Stewart (2007), and James Foyce. A Biography by Gordon Bowker (2011).

5. Nora: the Real Life of Molly Bloom by Brenda Maddox (1988). The biography was adapted for screen by Pat Murphy and a biopic entitled Nora was released in 2000 with Ewan McGregor and Susan Lynch playing the roles of James and Nora respectively.

6. John Stanislaus Foyce. The Voluminous Life and Genius of James Foyce's Father by John Wyse Jackson and Peter Costello (1998).

7. The final line of Joyce's poem "A Flower Given to My Daughter".

8. In Ellmann's biography Lucia is often mentioned en passant as a companion of her parents (when visiting the theatres of Paris), an object of Beckett's affection, and a "tortured" girl that requires Nora's vigilance since she disrupts her father's work; her "condition" is mostly alluded to (or referred to using some medical terminology) and never sufficiently explained or contextualised (Ellmann 649,662, 665).

9. I am very much aware of an essentially sexist method of referring to female subjects by their first names only (and to male subjects by their surnames) - unfortunately, an 
ignoble practice of many biographers. Consequently, I wish to emphasise that whenever I refer to Lucia Joyce as Lucia, I do it exclusively for the reasons of style.

10. In June 1988, during the $11^{\text {th }}$ International James Joyce Symposium, Stephen J. Joyce also announced that he had destroyed all the letters sent to him by Lucia as well as correspondence to Lucia from Samuel Beckett (James 1988).

11. In recent life writing criticism, "biofiction" appears to have substituted its longer equivalent, namely biographical fiction, or biographical novel (cf. Middeke and Huber 1999).

12. Her condition was alternatively diagnosed as neurosis, catatonia, cyclothemia (Shloss 3-4).

13. Shloss writes that her book is built on "reversals of other narratives" (Shloss 29).

14. "Whatever she said or did went into a book" (Shloss 455). Frances Stonor Saunders defines the relationship between Joyce and his daughter as folie à deux: "bound by a private language, baffling to others, that flared up in his work and transmitted the spark of inspiration to his daughter, kindling 'a fire in her brain'. Before it consumed her, the fire fuelled Lucia's talent for dancing" (Saunders 84).

15. Hastings's previous dramatisation (and re-vision) of modernist lives was his 1984 bioplay entitled Tom and Viv which focused on the relationship between T.S. Eliot and Vivienne Haigh-Wood Eliot. The play does not only emphasise Viv's contribution to her husband's oeuvre but also blames Eliot for her mental disintegration and demise. In his review of Calico for James foyce Quarterly, Arnold Goldman also paid attention to the fact that in interviews and other writings Hastings "emphasised the wrenching disaster of the breakdown and the obsession of the Joyce Estate with eliminating Lucia from the record" (Goldman 888).

16. They also died there: Violet Gibson in 1956, and Lucia Joyce in 1982.

17. Saunders reports that when Helen McTaggart sent pen, paper and envelopes to Lucia, she was rebuked by the senior nursing sister and the items confiscated (Saunders 272). She also notes that Lucia arrived at St. Andrew's (on March 15, 1951) with "a few possessions and a carton of Lucky Strikes" (Saunders 320).

18. The only formal element that differentiates "the Lucia story" from "the Mary story" is that the former is black and white, while the latter is coloured in sepia tones.

19. The fourth page of Dotter of Her Father's Eyes shows Mary M. Talbot travelling on the train and reading Shloss's Lucia foyce: To Dance in the Wake.

20. "Whatever spark or gift I possess has been transmitted to Lucia and it has kindled a fire in her brain" (James Joyce qtd. in Shloss 7).

21. When learning that Lucia's dancing and teaching has been disapproved of by Nora Barncacle, Stella Steyn, Lucia's friend, concludes: "Oh dear. I expect you are too modern for her, Lucia" (77, emphasis in original).

22. Margaret Morris was the first to introduce the Isadora Duncan technique to Great Britain.

23. Samuel Beckett (and his chauvinism) is not spared by the narrative either. When Lucia talks to him about Madame Morris qualifying as a physiotherapist and earning a degree, Beckett ironically reacts with the expression: "How modern!" (73, emphasis in original).

24. It appears to me that Mary M. Talbot deliberately refrained from narrating the years that followed the attack on Lucia's mother (especially the period between 1932 and 1936 


\section{ROBERT KUSEK}

which witnessed numerous episodes of Lucia's self destructive and violent behaviour) since it would be impossible to ignore facts testifying to Lucia's serious mental disorder. In turn, this would seriously undermine Talbot's vision of Lucia as a victim of her father's egocentrism and the family's indifference to her needs.

25. One image shows Mary M. Talbot being inquired by a female friend (upon learning that the former is reading a biography of Lucia Joyce) in the following manner: "So you're finding parallels?" Though Mary answers "I bloody hope not" it is clear that identifying thematic and diegetic similarities lies at the very heart of Dotter of Her Father's Eyes. What is more, the front cover of the book shows the image of Mary M. Talbot, while the back cover displays the face of James Joyce.

26. She even suffers from bronchitis as a result of his chain smoking.

27. In one of the sections dedicated to Lucia, James Joyce implores his daughter: "let's not have one of your King Lear scenes" (70).

28. After "a nicens little boy named baby tuckoo" from the opening sentence of $A$ Portrait of the Artist as a Young Man.

29. A phrase from Giacomo foyce.

30. This procedure seems to be particularly adequate when considering James S. Atherton's scholarly exploration of intertextuality in the works of James Joyce.

31. Similarly, James S. Atherton can be seen as the later version of James Joyce. Recent biofictions have shown a considerable preference for narrating transdiegetised life. For example, in The Hours (1998), Michael Cunningham has taken Virginia Woolf (and her character Mrs. Dalloway) and re-located her to early $21^{\text {st }}$ century New York City. Maria, the major protagonist of Rosalin Brackenbury's tellingly titled novel Becoming George Sand (2011), re-lives the life of George Eliot, including an episode of travelling with a younger (Chopin-like) lover to Majorca.

32. Of course, the question of "sameness" and "difference" could be further explored taking into account either the process of rendering one's life through discourse, or (alternatively) an inevitable reduction to sameness by reason's desire for totality.

33. On a number of occasions Bryan Talbot refuses to be simply a copyist or illustrator and, using his own medium, i.e., drawings, he disturbs the story narrated by his wife. For example, in a classroom he makes Mary sit next to a boy, to which she responds with the following footnote: "Brian's wrong again. In my school boys were seated on one side of the classroom, the girls on the other. Always" (18). Also, he slips into his favourite childhood book an image showing Mary surrounded by her favourite readings (14).

34. In her brilliant reading of genealogy of memoir entitled "Are Memoirs Autobiography?" Julie Rak pays attention to the transgendered nature of this type of writing since - all at once - it blends private and public; its subject may be one's self or others; it is equally written "by the most powerful public men" and "the least known, most private women" (316); it describes "writing as process and writing as product" (317). What is more, "memoir" is inconsistent in number and gender: the term can be both singular and plural (and mean the same!) and, most interestingly, it has been both a masculine and feminine noun. Finally, it profoundly violates the laws of genres since it can be "a document note or a record, a record of historic events based on the writer's personal knowledge or experience, an autobiography or a biography, an essay, or a memory kept of someone" (ibid.). 
35. Due to it being primarily associated with the notion of funniness.

36. Interestingly (and, I believe, purely incidentally), Vladek's first recollection that he shares with his son is concerned with his girlfriend whose name is Lucia [sic!].

37. In an interview with James E. Young, Art Spiegelman says: "Maus is not what happened in the past, but rather what the son understands of the father's story" (Young 2006, 250).

38. E.g. Darwin by Eugene Byrne (2012) or Rembrandt by Raymond Koot (2012).

39. E.g. Alison Bechdel's Fun Home (2006), or Matilda Tristram's cancer graphic memoir entitled Probably Nothing (2014).

40. Both "states" and "dispositions" as understood by Richard Wolheim (6-11).

41. Nussbaum claims that emotions have cognitive dimension and are frequently "more reliable and less deceptively seductive" than "intellectual calculations" (Nussbaum 1992, $40,41)$. She also states that they "all are belief-based $[\ldots]$ : all involve the acceptance of certain views of how the world is and what has importance" (ibid.).

42. In particular chapter 13 of Love's Knowledge tellingly entitled "Narrative Emotions: Beckett's Genealogy of Love" (286-313).

43. In fact, one could further explore similarities between Molloy and Dotter of Her Father's Eyes. Both narratives concern two principal characters who, with time, merge and, having similar thoughts and experiences, become distinguishable primarily by means of their "vital statistics".

44. And which, in fact, can be extended to any life narrative. Emphasis added.

\section{Works Cited}

Beckett, Samuel. Molloy, Malone Dies, The Unnamable. London: John Calder, 1994. Print.

Couser, G. Thomas. Memoir: An Introduction. Oxford: Oxford University Press, 2012. Print.

Ellmann, Richard. James foyce. Oxford: Oxford University Press, 1982. Print.

Everett, Barbara. "Alphabeted." London Review of Books Issue 25, 2003: 6-10. Print.

Genette, Gérard. Palimpsestes. La littérature au second degré. Paris: Éditions du Seuil, 1982. Print.

Gilmore, Leigh. The Limits of Autobiography. Trauma and Testimony. Ithaca and London: Cornell University Press, 2001. Print.

Goldman, Arnold. "Calico by Michael Hastings. A Review." James Joyce Quarterly Volume 40 Number 4, 2003: 888-894. Print.

Janzen Kooistra, Lorraine. "The Biography of the Century': Another Look at Richard Ellmann's James foyce." Biography 16(1), 1993: 31-45. Print.

James, Caryn. "The Fate of Joyce Family Letters Causes Angry Literary Debate." The New York Times 15 August 1988. Web. 14 December 2014. 
Joyce, James. Finnegans Wake. Oxford: Oxford University Press, 2012. Print.

Lee, Hermione. Body Parts. Essays on Life-writing. London: Chatto and Windus, 2005. Print.

Lessing, Doris. Under My Skin. Volume One of My Autobiography to 1949. New York: Harper Perennial, 1995. Print.

Mantel, Hilary. Giving up the Ghost. A Memoir. London: Fourth Estate, 2010. Print.

Middeke, Martin and Werner Huber, eds. Biofictions: The Rewriting of Romantic Lives in Contemporary Fiction and Drama. Columbia S.C.: Camden House, 1999. Print

Nussbaum, Martha C. Love's Knowledge. Essays on Philosophy and Literature. New York and Oxford: Oxford University Press, 1992. Print.

---. Upheavals of Thoughts. The Intelligence of Emotions. Cambridge: Cambridge University Press, 2008. Print.

Olney, James. "(Auto)biography." Southern Review 22, 1986: 428-441.

Rak, Julie. "Are Memoirs Autobiography? A Consideration of Genre and Public Identity." Genre 36, 2004: 305-326. Print.

Rich, Adrienne. On Lies, Secrets and Silence. New York: W.W. Norton, 1979. Print.

Saunders, Frances Stonor. The Woman Who Shot Mussolini. London: Faber and Faber, 2010. Print.

Shloss, Carol Loeb. Lucia foyce: To Dance in the Wake. London: Picador, 2005. Print.

Smith, Dinitia. "A Portrait of the Artist's Troubled Daughter." The Nerw York Times. 22 November 2003. Web. 8 December 2014.

Spiegelman, Art. "Commix: An Idiosyncratic Historical and Aesthetic Overview." 42(6), 1998: 61-73. Print.

Wolheim, Richard. On the Emotions. New Haven and London: Yale University Press, 1999. Print.

Young, James E. At Memory's Edge. After-Images of the Holocaust in Contemporary Art and Architecture. New Haven and London: Yale University Press, 2000. Print.

--.."The Art of Jewish Memory in a Postmodern Age." Meaning and Representation in History. Ed. Jörn Rüsen. New York and Oxford: Berghahn Books, 2006: 239-254. Print. 
ROBERT KUSEK is an Assistant Professor in the Department of Comparative Studies in Literature and Culture at the Institute of English Studies of the Jagiellonian University in Krakow, Poland. His research interests include the oeuvre of J.M. Coetzee, the contemporary novel in English as well as a comparative approach to literary studies, life writing genres, the poetics of memory and loss, the Holocaust and its representations in culture, intercultural communication and media. He is the author of a monograph and over twenty academic papers published in books and academic journals, as well as the co-editor of five volumes of articles.

robertkusek@gmail.com 